\title{
Büyük Anlatının Yitimi \\ Doğrultusunda documenta 8'de Yeni Yaklaşımlar
}

\author{
Seda Tezcan \\ Hacettepe Üniversitesi Güzel Sanatlar Enstitüsü \\ Resim Sanatta Yeterlik Programı \\ seda.tezcann@hotmail.com \\ ORCID: 0000-0001-6998-1351
}

\begin{abstract}
Öz
1987'de 8'incisi düzenlenen documenta sergisi, teorisini dönemin gerekleri doğrultusunda kaçınılmaz bir durum olan postmodernizm üzerine inşa eder. Yeni bir sosyal durum olan postmodernizm ile birlikte üst anlatılar gücünü yitirir, otoriteler sorgulamaya açılır. Bu durum yeni tutumları ve yeni bir eser dilini gerekli kılar. Bu doğrultuda sanatın sosyal bağlarını sorgulayan documenta 8 , yeni tutumlar ve yeni biçimlerin denendiği bir alan haline gelir. Sergide yeni yaklaşımlarla döneminin sanatsalve kültürelyapısına cevaplar arandığısöylenebilir. Buyaklaşımlar teorik tartışmaların temelini oluşturur ve eserlerde kendini gösterir. Postmodern epistemolojik yöntemin ağır bastığı teorik yaklaşımlar ve yaratım pratikleri, sanat eserinin yeni konumunu ve sorumluluğunu sorgulamaya açar. documenta 8' de geçmiş ve güncel olan arasında hem bir köprü kurulur hem de geçmiş ve güncel durum arasında kıyaslamalar yapılır. Sergi bir yandan kendi birikimini muhafaza ederken bir yandan da güncel kııımalar ile yakından ilgilidir. Eleştirel ve deneysel bir yapı ile kurgulanan sergi yeniliklerin sınandığı bir mutfağa dönüşür. Hala güncelliğini koruyan sosyal ve plastik sorgulamalar, serginin teorik alt yapısı incelenerek ve eserler ile örneklendirilerek gözden geçirilebilir.
\end{abstract}

Anahtar Kelimeler: documenta, documenta 8, postmodernizm, sergi, sivil itaatsizlik

Tezcan, S. (2021). Büyük Anlatının Yitimi Doğrultusunda documenta 8' de Yeni Yaklaşımlar. ARTS: Artuklu Sanat ve Beşeri Bilimler Dergisi, 6, 95-110 


\title{
New Approaches at documenta 8 in Line with the Loss of the Grand Narrative
}

\begin{abstract}
The documenta exhibition, organized fort he 8th time in 1987, builds its theory on postmodernism, which is an inevitable situation in line with the requirements of the epoch. With postmodernism as a new social situation, meta-narratives lose their power. Authorities open up for discussion. This situation requires new attitudes and a new language of work. Accordingly questioning the interpersonal ties of art, documenta 8 becomes a place where new attitudes and new forms are tested. It can be said that the exhibition seeks answers to the artistic and cultural structure of the epoch with new approaches. These approaches form the basis of theoretical discussions and are reflected in the works. The theoretical approaches and creative practices dominated by the postmodern epistemological method open up the new positions and responsibilities of the work of art to question. In documenta 8, a bridge is built between the past and the current, and comparisons are made between the past and the current situation. While the exhibition preserves its own accumulation, it is also closely related to new situations. Constructed with a critical and experimental structure, the exhibition turns into a kitchen where innovations are tested. Social and plastic inquiries that ar stil up to date can be reviewed by examining the theoretical infrastructure of the exhibition and illustrating it with works.
\end{abstract}

Keywords: documenta, documenta 8, postmodernism, exhibition, civil disobedience 


\section{arts}

\section{GíRiş}

1955'te, Arnold Bode tarafından Kassel'de başlatılan documenta sergileri, her sergi ile birlikte, sanatın sunumuna ve temsil edilişine yeni bakış açılları kazandırmış ve yoğun tartışmalara sebep olmuştur. Her dönem kendi güncelini bir şekilde yakalamayı başarmış ve çoğunlukla sanata yeni yönelimlerin eklemlenmesine katkı sağlamıştır. Bu etkileri göz önünde bulundurulduğunda, documenta sergileri, sanatın kendi tarihsel hareketi bağlamında incelenmeye ve yorumlanmaya değerdir.

1987'de düzenlenen documenta 8, plastik sanatların alanına yeni dahil olan postmodernizmi sergi gündemine taşımıştır. Bu durum, teorik tartışmalara ve yeni pratiklerin bir arada sınanmasına sebep olmuştur. Hem documenta 8'in kendi tarihsel birikimi açısından bir kırımaya sebep olan hem de sanata yeni bağlam ve biçimler kazandıran bu durumu, bugünün gözünden değerlendirmek düşünce ve ifade biçimlerine yenilikler kazandırabilir. Bu nedenle öncelikte documenta'nın tarihine kısa bir bakış atıp, ardından documenta 8' deki yenilikleri, teorik ve biçimsel açıdan incelemek iyi bir yol olabilir.

1955'te düzenlenen ilk documenta sergisi, Nazi döneminde "yoz sanat" olarak Almanya kültür ortamından dışlanan, döneminin günceli olan ve aslında dünyanın gerçekliğiyle sıkı bağları olan sanatsal eğilimleri, Alman kültürüne kazandırmayı sorumluluk olarak almıştır. İlk documenta "Nazizmin kültürel karanlığını bastırmak ve ortadan kaldırmak", kültürel açıdan "Almanya'yı modern sanat aracılığıyla hızlandırmak" görevini üstlenmiştir. (Bakargiev'den aktaran Roberta Smith, 2012). Dünya sanatı ile Alman sanatı arasındaki uçurumun kapatılmasına ihtiyaç duyulmuştur. Ama sergi bu amaç ile sınırlı kalmamış, özgün sergileme biçimleri ve kültürel birikim üzerine geliştirilebilir modern bir yenilikçilik ahlakını da yapılandırmayı başarmıştır.

Her beş yılda bir Kassel'de düzenlenmeye devam edilen documenta sergilerinde, odak nokta çağdaş durumların üzerindedir ve documenta, yalnızca birikimi sunmaktansa bu birikime yön veren ve alternatif yaklaşımlar yaratan önemli bir sergi haline gelmiştir.'

Bu makalede inceleyeceğimiz documenta 8 sergisi, plastik sanatların alanına diğer disiplinlere kıyasla geç giren ve hala güncelliğini koruyan bir tartışma konusu olan postmodernizmi bir sorgulama olarak konusuna dahil etmiştir. documenta 8'in sanat yönetmenliği Manfred Schneckenburger tarafından üstlenilmiş ve teorik

1 documenta kültürünün şekillenmesi ve ilk 4 documenta sergisi ile ilgili geniş çaplı bilgiye Necla Rüzgar Kayıran'ın "Bir Fikrin" Başarı Öyküsü: documenta adlı makalesinden ulaşılabilir. 
güzergahı yine onun tarafından yapılandırılmıştır. Sanatçıların ve yönetim kurulunun postmodern tutumlar çerçevesinde, teori ve pratik arasındaki çatışmaya yeni yaklaşımlarla çözüm yolları aradıkları söylenebilir.

Medya estetiğinin biçim ve temaya olumlu bir şekilde dahil olduğu 60'lara kıyasla, documenta 8'de, 70'lerde olduğu gibi sosyal bağlama önem verilmiş ve ağırlıklı olarak medyaya karşı eleştirel bir tutum sergilenmiştir. "Yetmişli yılların sanat üreticileri sosyal duyarlılık taşırlar ama politik anlamda son derece etkisizdirler" (O'Doherty, 2013, s. 100). documenta 8'de, 70'lerin aksine sanatçılar politik meselelere kayıtsı değildir ve sosyal bağlamı politik meseleler üzerinden ele alırlar. Medya eleştirisi de kendini konuya bu noktada dahil eder. Teori ise yeni epistemolojik yöntemlerin biçimsel karşlıklarını tartışma konusu haline getirir.

documenta 8, postmodernizmi bugün hala aşina olunan sosyo-politik ve epistemolojik problemler üzerinden ele alır. 80'lerde neo-ekspresyonizm, sokak sanatı, politik temellük, kavramsal soyut ve kavramsal minimalizm gibi yaklaşımlar popülerlik kazanmış, postmodernizm ise sosyal, kültürel ve politik açıdan tüm disiplinleri domine etmeye başlamıştır. ${ }^{2}$ documenta $8^{\prime} \mathrm{i}$, postmodern teorik yaklaşımlar ve bunların pratiğe aktarımı üzerinden incelemek hala güncel olan bu problemlere yeni bakış açıları kazandırabilir. Serginin bütünlüğü ve eserlerin bu konu ile nasıl bir tutumla ilgilendiği, başarıları ve başarısızlıkları tartışmaya açılabilir. Bu açılardan incelendiğinde documenta 8 sergisi, güncel kültürel problemlerin bir kısmının temellerine yol haritası olabileceği gibi, plastik anlamda çözüm ip uçları da barındırmaktadır.

Bunun için öncelikle documenta 8'in teorik alt yapısına bakmak ve dönemi serginin gözünden ele almak gerekmektedir.

\section{documenta 8'in Teorik Yapısı ve Yeni Yaklaşımlar}

documenta 8, 1987' de önemli politik değişimlerin olduğu bir döneme denk gelmiştir. Bununla birlikte documenta 8 'in bir sorumluluk olarak gördüğü konu, güncel ve sosyal olan sorunlarla ilgili bir tutum içerisinde olmaktır. Batı dünyasında yükselen sağcı popülizm ve neoliberal eğilimler tüm dünyayı etkilemiş ve bugünün yapısının bir nevi ön kurulumu olmuştur. 80'leri hazırlayan süreç ise 60'larda şekillenmeye başlamıştır. 60'larda batıda sanatsal aktivitelerin öncülük ettiği ayaklanmalar ve itirazlar geniş çaplı yankılar uyandırmıştır. Postmodernizmin de aynı şekilde 60'larda 2 Süreç ve sanatçı örnekleri incelenmek istenirse Jonathan Fineberg'in "1940'tan Günümüze Sanat: Varlık Stratejiler" adı kitabı aydınlatıcı bir kaynak olabilir. 


\section{arts}

tartışılmaya başlandığı, dönemin değişiklerinden türediği ve yirmi yıl içerisinde birçok disiplini etkilediği yorumu documenta 8'in gözünden şu şekilde sunulur:

1960'lardan bu yana edebiyat ve edebiyat araştırmalarında bir tür söylem ve kültürel bir hareket olan postmodernizm, sanat alanına geç girdi, giriş öncelikle eklektik tarihselci mimari kuram ile yumuşatıldı. 1980'lerin sonunda modern-postmodern tartışması, Almanya'daki kültürel söylemi domine etti. Bu tartı̧̧ma yergi ve savunma üzerinden üretken bir haldeydi (Bippus, 2005, s. 317).

Almanya'da tartışmalara ve fikir ayrlıklarına sebep olan postmodernizm, documenta 8'in sanatsal danışma kurulunda da farklı eğilimlere sebep olmuştur. Neredeyse herkes bu yeni yapıyı kendi görüş ve sanatsal beklentilerine göre yorumlamıştır. Bu farklı bakış açıları, sanata farklı sorumluluklar yüklemektedir. documenta 8 kataloğundan yorumlandığı kadarıyla bazıları yeni avangardın mümkünlüğünü sorgularken, bazıları ütopyacılığı "terör şüphesi” ile değerlendirmiş, bazıları postmodernizmi yeni bir modernizm olarak algılamıştır (Bippus, 2005, s. 317). Ancak sonuç olarak bugün bilinmektedir ki postmodernizm ne yeni bir avangardı mümkün kılmakta ne de modernizme benzemektedir. Teorik tartışmalar için bütünlüklü bir tespiti ve tanımlamayı mümkün kılmayan bu eklektik sosyal durum, documenta 8' de akla gelebilecek birçok açıdan hem teorik bazda hem de eserler ile deneylere tabi tutulmuştur denilebilir. Manfred Schneckenburger'in yaklaşımının ise bu yeni durumun tematik açısını çizerken, ona modernist bir eğim kazandırmak olduğu ifade edilmektedir (Bippus, 2005, s. 317). Bu yaklaşım kurgulanırken, modern ve postmodern dönemde sanatın işlevi ve sorumluluğu arasındaki en net farkın ne olduğu da sorgulanmıştır. Schneckenburger sergi ile ilgili röportajında modern sanat ile 80'lerin sanatı arasındaki farkı documenta 8'in bağlamı ile ele almıştır. Modern sanat akımlarının tetikleyici ve harekete geçiren etkisi, yani gücünü rahatsız ediciliğinden alan unsur, 80'lerin kültürel ve sosyal ortamında mümkün değildir. Bu nedenle 80'lerden itibaren eserin niteliğinin ve sorumluluğunun büyük oranda değişime uğradığı söylenebilir.

Sanat eserinin niteliğini değiştiren bu durum, yine dönemin kendi dinamiklerinin bir sonucudur. Jean-François Lyotard, Postmodern Durum adlı kitabında, bilginin meşruluğunun ve güvenilirliğinin bir iktidarlaşma problemi olduğundan ve bu yüzden de tartışmaya açık olduğundan bahseder (2019, s. 22). Bilgi, meşruluğunu bilimselliğinden değil, bilgiyi ortaya koyanın ekonomik gücünden ya da totaliter tavrının başarısından alır. Bu irrasyonel güvencesizlik, kavrama, sahiplenme ve tepki verme kültürünü büyük oranda etkiler. Toplumun sekülerleşmesi ve bireyciliğin aşırıya 
kaçacak düzeyde önem kazanması da toplumsal değerlerin sahiplenilmesini ya da hangi değerin sahiplenilebileceğini problem haline getirmiştir. Bir başka sebep de batıda gittikçe yerleşen sosyal devlet anlayışıdır. Sosyal devlet anlayışının olumsuz etkisi, bireysel inisiyatifin toplumdan çekilmesine sebep olmasıdır. Bunlardan dolayı sanat eserinden tetikleyici bir etki beklemek çok da mümkün değildir. Bu noktada avangard sanatın tetikleyici yönü düşünülerek durumun sonucu örneklendirilebilir. Zamanında toplumsal değerlerin ikiliğini ve pratikteki çalışmayışını, bu değerlere saldırarak ve insanları tetikleyerek açığa çıkaran sanatçılar, karşılarında aşınmaya müsait sinirli bir yığın muhatap bulabilirken, 80'lerden itibaren böyle bir etki uyandırmak mümkün olmamıştır.

Lyotard'ın "postmodern durum" olarak adlandırdığı yapıda bu durumun temeli "büyük anlatının yitirilişi" tespiti ile sunulur, "postmodern" sayılan tutum, "üstanlatılara karşı inançsızıktır." (Lyotard, 2019, s.8). Bu kapsayıcı anlatıların işlevsizliğinin yukarıda bahsedilen olumsuz durumlarla bağlantıları vardır. Ancak bu anlatılarla birlikte, anlatıların iktidarı ve baskısı da ortadan kalktığı için bu durum ilginç bir özgürlük alanı da açar. Bu özgürlük alanının keşfi aşağıdaki ifadelerden anlaşılabilir:

Kassel'de dünyanın tüm bilmecelerini tek bir teori ile çözen tematik ansiklopedilerdeki inanç -sergileri eserlerin skalasını tek bir sloganla kavranabilir hale getiren sistem-artık bitti. Başka bir deyişle, Schneckenburger, postmodernist dokunun doğrultusunda, anlatımcı konsepte ve böylece, tarihsel ilerlemeyi temsil etmenin başlıca yollarından birine, evrimsel konsepte ve evrensel değerlere veda ediyor (Bippus, 2005, s. 317).

Artık mesele bu alanın nasıl bir tutum ile değerlendirileceğidir. Bu yaklaşım ile documenta 8'de tüm epistemolojik temel, üst yapının tasfiyesi ile değiştirilir. Zaten problemli olan teori ve pratik uyuşmazlığı, tarihsel açıdan çözüme ulaşmadan daha da karmaşık bir hale gelir. Aynı zamanda bu durum documenta sergilerinin documenta 8'e kadar inşa ettiği birikim kültürüne de aykırıdır. Ancak sergi düzenleyicileri birikim ve yeniliği bir arada sunarak, bu durumu belki de bir geçiş dönemi haline getirmişlerdir. Farklı eğilimleri bir arada sorgulayarak ucu açık bir durum değerlendirmesine ve yapı üretme denemesine girişmişlerdir.

Schneckenburger'in teori ve pratiğin geleneksel ikilemine dayanan argümanı, sergileme şeklini teori ve bireysel iş temeli olarak var sayar. Teori üst yapıyı işareł eder. Bireysel iş nesnelleşir: özerk ve kendi kendine yeten, temel unsurun kendisi olur, diğer bir yandan metin ise, eserde temellense de kendi başına bir yapı olarak da varlığını ortaya koyar (Bippus, 2005, s. 318).

Üst yapı ya da birleştirici ve bütünleştirici bir ortak sosyal durum, artık yaşamın kendisinden tespit edilip alınamamaktadır. documenta 8, temel temanın yerini 


\section{arts}

alacak bu yapıyı, dönemin dinamiklerini değerlendirilerek ortaya konan eklektik teorilerle telafi etmeye çalışır. Bu teoriler, neyin elle tutulur biçimde ve somut bir şekilde ele alınabileceği ve bu parçaların nasıl bir tutumu gerekli kıldığı üzerine şekillendirilmeye çalışımıştır denilebilir.

Eserler temelinden değerlendirilecek olursa, tutum eleştirel ve ironiktir. Bu noktada Lyotard'ın postmodernizm kuramı tekrar devreye girer. O, dönemin epistemolojik totalitarizmini ancak oyuncu bir dilin aşabileceğine inanmıştır. Lyotard, "dil oyunlarının ortada toplum diye bir şey olabilmesi için mutlaka istenen minimum ilişki türü" olduğunu belirtir, ona göre bilginin alıcısı olan ve bilgiden etkilenen kamuoyunun, bu iktidar alanında aktif olabilmesinin koşulu, bu sorgulayıcı tutumdur $(2019$, s. 37). Aynı zamanda bu dil, karşıt yapıyı işaret edip problemi açığa çıkarabilir ve yapıyı işlevsizliğin çelişkisine düşürebilir. Postmodernizmin epistemolojik hiyerarşisi, bu iletişim modelini gerekli kılmışıı. Bu oyuncu dil, birikimin muğlaklığını ve eksikliğini açığa çıkarır ve eleştirel bir tutum olarak muhatabına geri döner. Lyotard'ın yöntemi, Bippus'un perspektifinden şu şekilde değerlendirilmiştir:

Lyotard postmodern epistemolojik yönteme "paraloji" olarak atıfta bulundu. Eğik, yanal ve yerleşik düşüncenin tersine paralojik düşünce anlamsal belirsizliği yansıtır. "Küçük anlatılar" biçiminde öngörülen hiperaktif estetik yıkım, yerleşik hiyerarşik yapıları patlatmaya hizmet eder. Kendini konumlandırmayı kolaylaştııı ve yıkıcılığı ne bilimin otoritesine ne de hakikat iddialarına saygı duyar (Bippus, 2005, s. 319-320).

Bahsi geçen "küçük anlatılar" eleştirel ve dirençli yapısını Michel Foucault'nun eleştiri kavramına kazandırdığı yaklaşımdan alır. Bu "küçük anlatılar"ın inşa edilişi ve documenta 8'in bu konudaki eğilimi neredeyse bir formül gibi açıklanmıştır.

Foucault, hakikat ve konu sorunlarını önerdiği tarihsel-felsefi pratiğe entegre eder. Foucault'ya göre kişi "gerçek söylem ve ona bağlı boyun eğdirme mekanizması olarak akılcılığın yapısı ve ilişkiler arasındaki soruların üzerinden geçmek yolu ile, kendi kişisel tarihini oluş̧turmalı, sanki bir kurgu gibi icat etmelidir.". Bu uygulama, herhangi bir girişimden ve kavramların incelenmesinden farklıdır. Tersine, teorik figürlere ve kökenlere başvurmayı dışlayan bir yaklaşımdır. (...) Bilginin mümkünlüğünün koşullarını, ürününü, déneyimsel temelini ve alımlanışını tarihsel kültüre eker ve onları söylemle ilişkili olarak analiz eder. Bu manada eleştiri prosedürleri kendi genel koşullarını dikkate alır, tarihsel olarak sınıfandırır ve böylece epistemolojik limitleri haritalandirabilir ve deneyimlenebilir hale getirir (Bippus, 2005, s. 319).

Tematik bir yaklaşım olarak değerlendirilebilecek bu eleştirel tutum, tepkisini bilginin üzerinde iktidar kuran sosyal yapıya yöneltir. Dilini de çoğunlukla onun medyumlarıyla şekillendirir. Estetiğin yerini eleştirinin aldığı, medya dilinin ağır bastığı eserler buna örnek verilebilir.

Bu formül sivil itaatsizliğin yapısını çağrıştırmaktadır. Bilginin tekelleşmesinin 
karşısında bir tepki ve meşruluğuna duyulan güvensizlik olarak sosyal yapılardaki hiyerarşiyi içinden çıkmadan boykot etmenin mümkünlüğü bu oyunla sağlanır.

Foucault, "yönetilmeme sanatı ya da daha iyi bir tabirle, bu şekilde ve bu bedelle yönetilmeme sanatı" şeklinde bir düşünce yolu kurguladı. Dışsal ve hukuki prosedürlerin yanı sıra bu, yönetilmeye karşı koyan "yansıtılmış inatçllık ve gönüllü itaatsizlik sanatı". Eleştirinin fonksiyonu "itaatsizliktir." Bu konuşma hakkının dirençli bir küstahlığını gerektirir (Bippus, 2005, s. 319).

documenta 8' de bu eleştirel ve itaatsiz tutum, Anna Oppermann'ın ve John Cage'in eserlerinde görülmektedir. Hans Haacke ve Leon Golub gibi sanatçılar ise medya simgelerini ve dilini, neoliberal politikaların iki yüzlülüğünü açığa vuracak şekilde ortaya koyarlar. Barbara Kruger, reklam estetiğini sosyo-politik sorunları açık eden ironik bir dile dönüştürür. Ian Hamilton Finlay de benzer bir şekilde politik bir sembolü, bu politik tutumun kendi kendisini açık etmesine sebep olacak şekilde kullanır. Ida Applebroog ise tarihsel anlatı meselesini, yeni bir tutumla ele alır.

\section{Teoriden Biçime}

Eserleri incelemeden önce, serginin genel atmosferini ve bahsi geçecek eserlerin tematik ortaklığını toparlamak gerekirse, documenta 8'in kendi güncelini ve sanatsal duruşunun birikimini harmanladığı söylenebilir. Yani ne ortaya çıkışındaki modernist ahlakı ve yarattığı kültürel birikimi dönemin koşullarından dolayı tamamen geride bırakmıştır ne de postmodernizmin gerektirdiği yeni tutumları reddetmiştir. documenta 8 "Sanat Yeni Bir Tarihsel ve Sosyal Boyut Kazanıyor" başlığını kullanmıştır. Bu başlık kurgulanmaya çalışılan dengeyi çok açık bir şekilde ifade etmektedir. Sanatın sosyal yapısı, kaçınılmaz bir şekilde kaide değiştirmiştir denilebilir.

Yeni biçimsel yaklaşımlar ve birikim söz konusu olduğunda, Anna Oppermann'ın Pathosgeste (Duygu Hareket) adlı eseri dönemin en karakteristik örneklerinden biri sayılabilir. Oppermann, belli tarih aralıklarında bir araya getirdiği ve kendi sistemine göre müdahale ettiği topluluklar (ensembles) yaratmaktadır. Enstalasyon da sayılabilecek bu birikimin malzeme ve disiplin sınırlaması yoktur. Gazete kesitleri, fotoğraflar, çizimler, objeler, yazılar, heykeller ya da akla gelebilecek her türlü buluntu ve yaratımıs malzemeyi kullanır. Bu malzemeleri farklı boyutlarda bir araya getirerek, tekrar tekrar çizerek ya da boyayarak çoğaltır ve yankılanmış bir ağ gibi bir araya getirir (Görsel 1, Görsel 2). Oppermann'ın üretim pratiği ile ilgili açıklaması şu şekildedir: 


\section{arts}

Topluluk formu benim etkileşim önerim. Bazlları için sübjektivist, otistikçe ve monomanik görünüyor. Yine de farklı disiplinler arasında, akıl ile duyusal algı arasında, sanat ile bilim arasında, sıradan vatandaş ile dışarıdaki arasında bir ara bulucu olmak istiyorum (Oppermann, 2007).

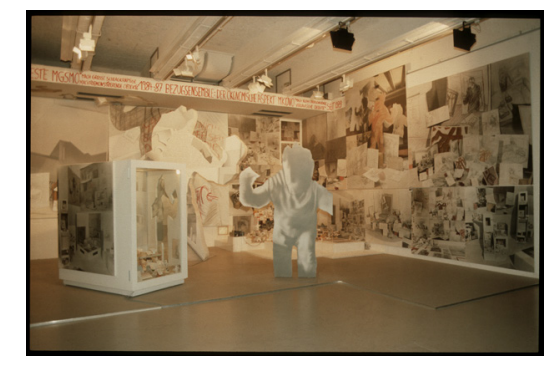

Görsel 1. Anna Oppermann, "Pathosgeste" (Duygu Hareket), enstalasyon, 1984-1987. (c) documenta archiv / Fotoğraf: Frank Mihm

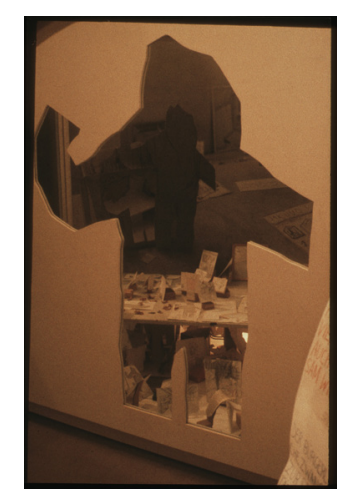

Görsel 2. Anna Oppermann, "Pathosgeste", eser ayrıntısI, 1984-1987. (C) documenta archiv /Fotoğraf: Kurt-Willi Julius

Oppermann biçimsel olarak, tarihsellik karşısında bilinçli bir öznel aşırlık sergiler. Bu tutumun "kararsızık lehine bir karar" ve "iletişime geçebilir olanın sınırlarını görünür hale getirme" olduğu ifade edilmiştir (Bippus, 2005, s. 322). Oppermann bu toplulukları bir araya getirirken bir bağıntı dizisi oluşturmamış, gündelik ve itkisel sınırları göz önünde bulundurmuştur. Bu tutum ile "Karmaşıklığın bu dünyanın bir yerinde hâlâ bir değeri olması gerektiğine" olan inancını ortaya koymuştur (Oppermann, 2007). documenta 8'de sergilenen topluluk Pathosgeste'de Oppermann, sanat piyasası ve sanatsal yaratım üzerine fikirlerini sergiler. Postmodernizmle ve postmodernizme karşı tutumlarla ilgili yazıları bir araya getirmiştir. Yerleştirmenin söylemi, mekânın ortasındaki figür ile eleştirel bir hal almaktadır. Bu figür, saldırgan bir tavır ile bir konuşmacının tavrı arasında asılı kalmış bir ifade sergiler. Bütünlüklü ve doğru bilginin mümkünlüğüne dair belirsizlik, figürün ifadesindeki karikatürize etki ile tamamlanmış olur. Bu yolla dönemin yapısına dair önemli bir konuya dikkat çeker.

Nihai bir durumun (postmodern) reddiyle, acil durum ve ortaya çıkma şifreleri yükselişlerini arzu ve ihtiyaçtan alırlar, "iyi yaşam" uğruna kendilerini durumdan duruma yeniden oluşturmazlar ve kalıcllık iddiasında bulunmazlar. Dünyaya bu şekilde bakmak, postmodernizmin rastgeleliği olarak damgalandı. 
Teori ve pratikte bu kısa okumaların amacl, ciddi postmodern kavramların hiçbir şekilde rastgele olmadığı, aksine rastgele yaşamı ciddiye aldıklarını göstermektedir (Bippus, 2005, s. 322).

Oppermann'ın bu tutumu ile rastgelelik, enformasyon sistemi karşııında bir tür sivil itaatsizliğe dönüşmüştür. Rastlantı üzerinden geliştirilen yeni biçimsel yaklaşımlar müdahale ve muhakeme kavramlarının temelindeki akılcı baskıyı tartışma konusu haline getirir. Bu uygulama biçimlerindeki rastlantısallık bireyin kabiliyetlerini, zekasını ve duruşunu gizlemez, aksine ön plana çıkarır. Henry David Thoreau, Sivil itaatsizlik metninde bu bireysel tutum çerçevesinde müdahalenin sınırlarının temellerini atmıştır.

\begin{abstract}
Ben tüm insanlara adil davranmayı ve bireye saygı gösterip, bir komşu muamelesi yapmayı beceren bir devlet tahayyül ediyorum. Böyle bir devlet, komşuluk ve insanlık görevlerini yerine getirmeleri kaydıyla, ona soğuk duran, onunla kaynaşmayan ve kendisinin de kucaklamadığı insanların varlığını kendi düzeni açısından bir sorun olarak görmez. Böyle meyveler veren ve onları olgunlaştıkları zaman da düşmeye bırakan devlet, hayalini kurduğum ama henüz hiçbir yerde görmediğim mükemmel ve şanlı bir devletin yolunu açabilir (Thoreau, 1997, s. 52).
\end{abstract}

Politik iktidar üzerinden tanımlanan bu tutum, totaliter mekanizmaları boşluğa sürükler. Oppermann, bu tutumu çağrıştıran bir yöntemle yargıda bulunma eylemini sorguya açmıştır.

John Cage, Essay (Deneme) adlı eserinde, Oppermann'dan farklı olarak, doğrudan sivil itaatsizlik kavramını biçime aktarmıştır ve onun da yaklaşımının temelinde rastlantısallık yatmaktadır. Eserini politik bir duruş ya da söylem etrafında şekillendirmemiş, böyle bir söylem yaratmamış, yalnızca bu biçimi bir deneyime dönüştürmüştür. Cage, bir ses enstalasyonu kurgulamıştır (Görsel 3) ${ }^{3}$. Rastlantısallığın metin kısmındaki biçimini, mezostik adı verilen bir algoritma yoluyla şekillendirmiştir. ${ }^{4}$ Cage, Erik Satie'nin Messe des Pauvres'ini ve Thoreau'nun Sivil itaatsizlik yazısı ile bu yöntemi kullanarak birleştirir, algoritmaya göre kendi döngüsel eksenini yaratan metin, üçüncü bir metin ve yeni bir biçim haline gelir. Cage, bu üçüncü metni sesini perdelemeler ve hızlandırmalar ile maniple ederek okumaktadır. Mekânın ışık düzeneği de öngörülemez bir düzene göre açılıp kapanmaktadır. Mekândaki sandalyelerin yeri her gün değişmektedir ve tüm bunlar mekânın da hareketli bir halde olduğu düşüncesini, burada yaşanan bir anın tekrarının olamayacağı düşüncesini çağrıştııır. Thoreau, daha yazısının en başında "En iyi hükümet, en az yöneten hükümettir." der (Thoreau, 1997, s. 30). Cage de yarattığı bu ses heykelinin yalnızca biçimini oluşturmuş ve seslendirmiş, geri kalan tüm unsurları rastlantının

John Cage'in Essay adlı eserinin görseli, documenta 8 sergisindeki düzenlemeye ait değildir. Mezostik algoritma ile ilgili bilgiye https://en.wikipedia.org/wiki/Mesostic adresinden ulaşılabilir. 
deneyimlenmesine ve ziyaretçilerin hareketine bırakmıştır. Sanatçı, eser ve ziyaretçi arasındaki müdahale zinciri ve hiyerarşinin sınırları bozulmaya uğratımıştır.

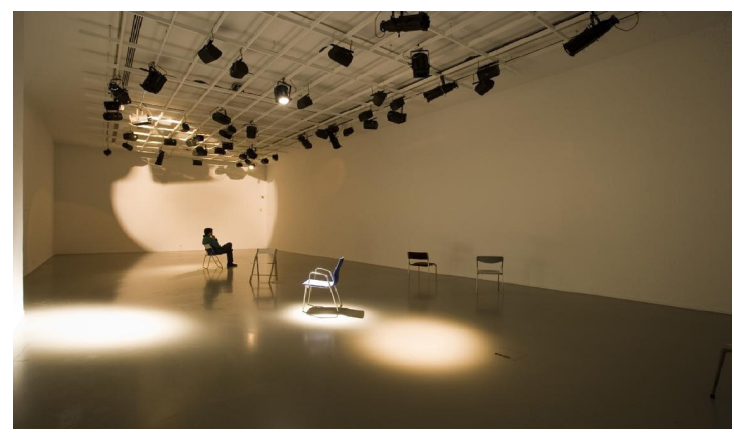

Görsel 3. John Cage, "Essay" (Deneme), ses enstalasyonu, 2006. http://bit.ly/35VOSIU

Lyotard'ın "dil oyunları" olarak adlandırdığı epistemolojik eleştiri ve direnme yöntemi Barbara Kruger'ın disiplininde çok net bir şekilde göze çarpmaktadır. Barbara Kruger, medya ve reklam estetiğinin dikkat çekme ve sansasyon yaratma amacıyla kullandığı dili ve grafik biçimini taklit ederek, kendi sosyo-politik söylemlerini yaratır. Bu ironik yaklaşım hem medyanın iki yüzlülüğünü ve onun gülünçlüğünü vurgular hem de asıl önemli sorunları ve gerçeklikleri bu yolla işaret eder. Kruger, documenta 8'de Endangered Species (Tehlike Altındaki Türler) adlı eserini sergilemiştir (Görsel 4).

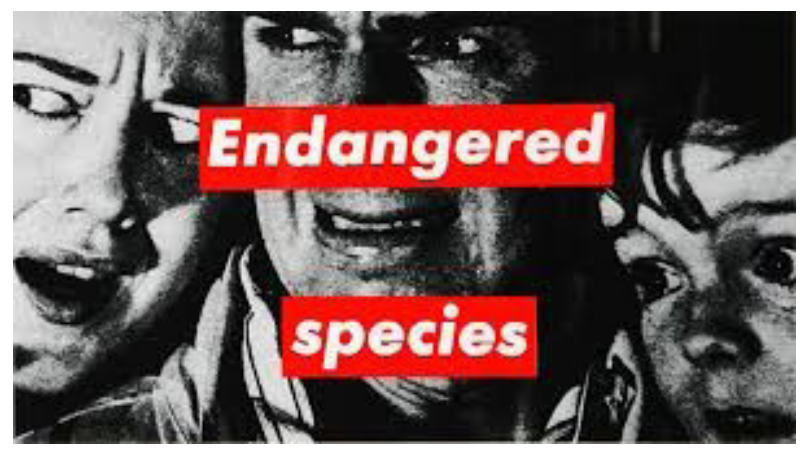

Görsel 4. Barbara Kruger, "Endangered Species" (Tehlike Altındaki Türler), fotoğraf, 1987. http://bit.ly/2LLYWSK

Hans Haacke, Kontinuität (Süreklilik) adlı eserinde (Görsel 5), Mercedes ve Deutsche Bank'ın logolarını kullanarak düzenlediği enstalasyonunda, Deutsche Bank'ın logosunun arkasına Güney Afrika'dan bir cenaze töreninin fotoğrafını yerleştirmiştir. Bilindiği kadarıyla Mercedes ve Deutsche Bank, 80'lerde Afrika'da ırk ayrımcılığını baskıcı yasalarla koruyan Apartheid rejimine karşı† politikaları desteklemeyi reddetmektedir. Bunun sebebinin kendi çıkarlarına yönelik politikalara uymaması olduğu bilinmektedir (Documenta 8, ). Haacke, çok doğrudan bir gönderme ile durumun altını çizmiştir. 


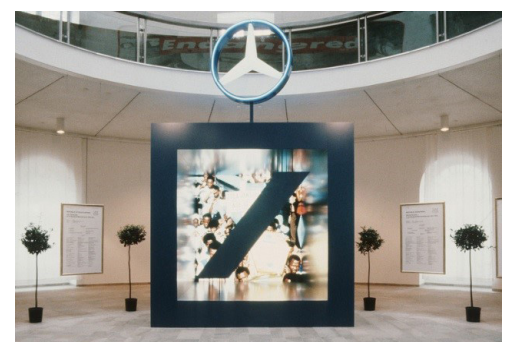

Görsel 5. Hans Haacke, "Kontinuität" (Süreklilik), enstalasyon, 1987. http://bit.ly/2M7SapD

Leon Golub, Interrogation IV'da (Sorgulama IV) aynı meseleyi şiddet ve korku temalarını kullanarak, bireysel duygular ve konumlar arasındaki hiyerarşi üzerinden ele almıştır (Görsel 6). Gazetedeki haber fotoğraflarından tuvale aktardığı sahneleri, bir dizi boya uygulamasından geçirmiştir. Figürlerin ifadelerini, onların duyguları arasındaki hiyerarşiyi işaret edecek şekilde, kişisel ve eleştirel bir gözle resme aktarmıştır. İşkence eden ve işkenceye maruz kalan figürler arasındaki vücut dili, kurban ve fail arasındaki dengeleri değişmeye mahkûm olan ilişkiye odaklanmaktadır. Emir zinciri ve baskı altında olma durumunun net bir şekilde sezildiği resimde, bu rollerin dengesinin güvencesizliği kurbanın fail, failin ise kurban haline gelebileceği gösterilmektedir.

Kurban/fail diyalektiği ve resmin şiddetin şekillendirdiği bir eylem olarak stilize edilmesi, genelleme ve ikiye ayırma iradesine aykırıdır. Ayrımcı bir eleştirinin temelini oluşturan bilgiyi göreceleștirir. Burada eleştiri bir tutumdur: sosyal ya da zihinsel hiyerarşilere teslim edildiği ve itaat ettiği anda çöker veya imkânsız hale gelir (Bippus, 2005, s. 321-322).

Golub'un yaklaşımı üst bakışı dışlar, ahlaki bir büyük anlatı derdi gütmez. Bunun yerine roller arasındaki hiyerarşinin altındaki insanlık durumunu ve bu hiyerarşinin irrasyonel yapısını gösterir.

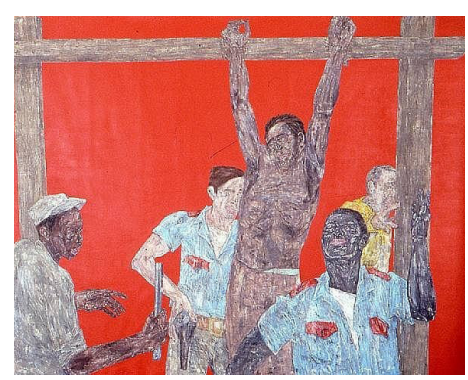

Görsel 6. Leon Golub, "Interrogation IV" (Sorgulama IV), keten üzerine akrilik, 1986. http:// bit.ly/3sFeNTn

Ian Hamilton Finlay, A View of the Temple (Tapınağın Bir Manzarası) adlı eserinde dört adet giyotin konstrüksiyonunu sergi alanının bahçesine dizmiştir (Görsel 7). Eserle ilgili olarak "Finlay'nin giyotinler üzerine yazdığı kısa metinlerde Fransız Devrimi' ne yapılan göndermeler, ütopik felsefelerin ne kadar kolay teröre ve 
şiddete yol açtığını hatırlatıı" yorumu yapılmıştır (Documenta 8, ). Finlay, bu yolla ütopik yaklaşımların ardındaki diyalektik dehşetle yüzleşme yaşatırken, bir yandan da şiddetin nesnesi aracılığıyla şiddetin temeline eleştirel bir yorum getirmiştir.

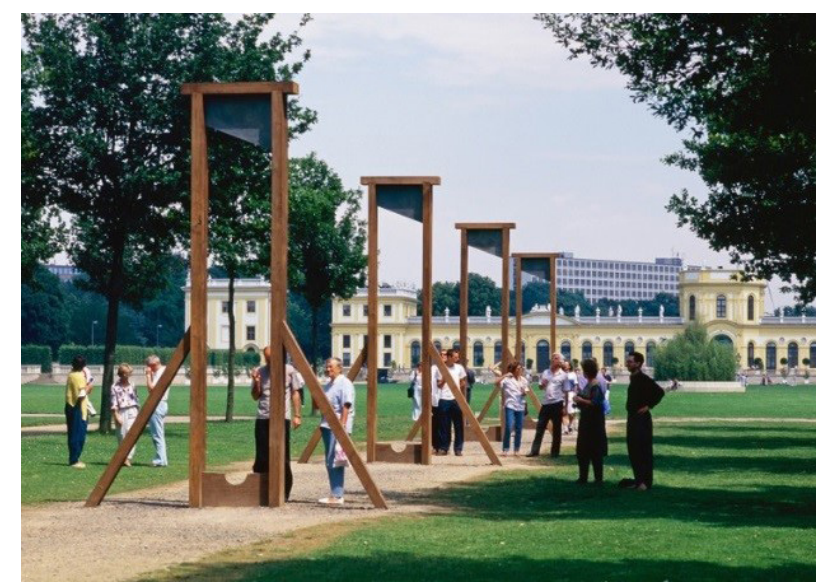

Görsel 7. Ian Hamilton Finlay, "A View of the Temple" (Tapınağın Bir Manzarası), enstalasyon, 1987. http://bit.ly/2M7SapD

Ida Applebroog'un Crimson Garden (Kızıl Bahçe) adlı eseri ise anlatıyı ele alış yönü ile ve biçimsel yenilikleri ile iyi bir postmodern resim örneğidir (Görsel8). Minimalist bir üslupla çizgi romanı andıran fragmantal sahneler bir araya getirilmiştir. Sade ve çocuksu üslubuna rağmen eser, Nazi dönemi ile ilgili güçlü bir eleştiri dili gütmektedir. Bu fragmanlar bir bütün halinde okunmaya çalışıldığında "anlatı sunmaz, daha ziyade anlatının kanıtını sunar" (Bippus, 2005, s. 321). Konusunun ve ifade biçiminin yanı sıra resimsel olarak da yenilikler sunmuştur. İlken anlatı sahnelemelerini andıran eser perspektif meselesine, resmin yüzey sınırlarına ve çerçevesine farklı bir yaklaşım sunuyor gibi gözükmektedir.

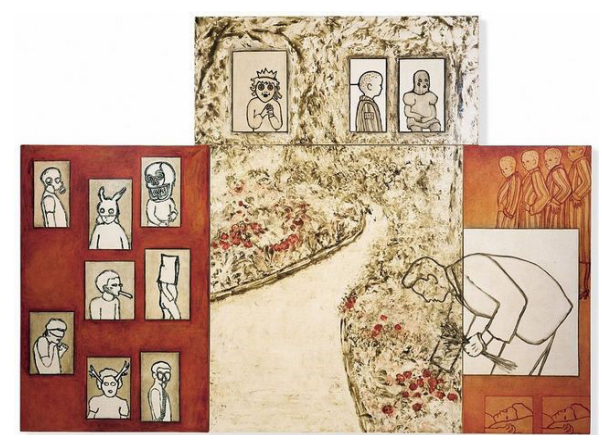

Görsel 8. Ida Applebroog, "Crimson Garden" (Kızl Bahçe). http://bit.ly/3qAZmtv

documenta 8, yukarıda bahsi geçen eserlerle değerlendirildiğinde, dönemin yeni koşullarında yeni tutumları bir araya getirmeyi başarmış bir sergidir. Sergideki birçok eserde 2. Dünya Savaşı teması, bellek kavramının tartışma konusu haline getirilmesi üzerinden eleştirel bir şekilde ele alınmıştır denilebilir. Christian Boltanski 
ve Tadashi Kawamata'nın eserleri bu konuda iyi örneklerdir. Boltanski, Les Archives (Arşivler) adlı eserde (Görsel 9) bir yığın çocuk fotoğrafını, fotoğrafların görüntülerini bozulmaya uğratarak sergilemiştir. Sergileme şekli ve fotoğrafların durumu değerlendirildiğinde, tarihsel bellek ve toplumsal anıların bozulması temaları öne çıkmaktadır. Tekrarlarla saf anlamı değişen travmatik tarihin, bozulması ve silikleşmesi fotoğraflar aracılığıyla konu edilmiş gibi gözükmektedir.

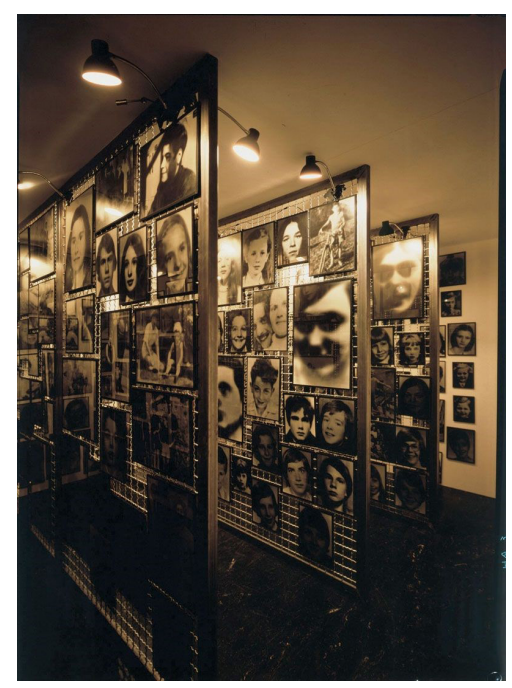

Görsel 9. Christian Boltanski. "Les Archives" (Arşivler), enstalasyon, 1987. http://bit.ly/2KA9ljy Kawamata ise Destroyed Church (Yıkılmış Kilise) adlı eserinde (Görsel 10) savaş döneminde zarar görmüş bir kilisenin kalıntılarının üzerinde, resimsel bir üslupla gerçekleştirdiği enstalasyonunda, yıkımın hareketini tekrar canlandırmıştır.

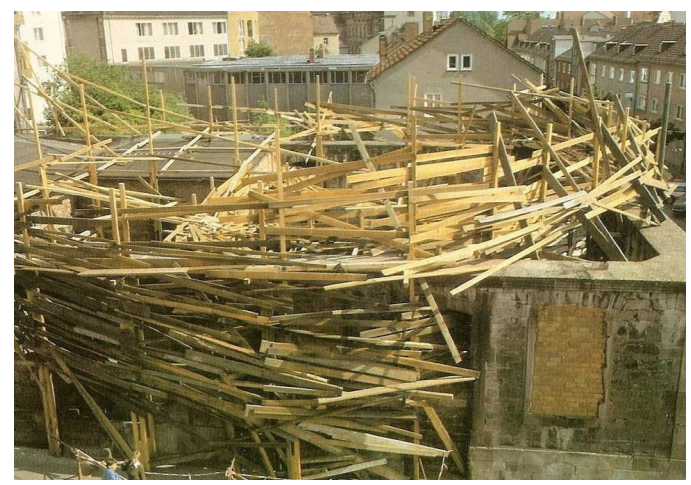

Görsel 10. Tadashi Kawamata, "Destroyed Church" (Yıkılmış Kilise), enstalasyon, 1987. http://bit.ly/3qDBxkC

Bunun dışında 1986 yılında, sergiden bir yıl kadar önce ölen Joseph Beuys'un anısına düzenlenen eserler, farklı çevreler tarafından beğeni ve eleştirilere maruz kalmıştır. Aynı şekilde birçok soyut sanat eserinin de serginin genel atmosferindeki dünyeviliğe uymaması eleştirilmiştir (Brenson, 1987). Beuys'un anısının baskın izi ve soyut sanata gösterilen eğilim, documenta'nın kendi birikimine sahip çıkan tutumu 


\section{arts $=$}

ile açıklanabilir. Ama genel eleştiriler serginin ne teorik anlamda bütünlüklü olduğu ne de seçkisiyle tutarlı olabildiği yönündedir.

\section{SONUÇ}

documenta 8' de yaklaşık beş yüz eser sergilenmiştir. Yukarıda, serginin teorik yaklaşımı ile en iyi örtüşen örnekler seçilmeye çalışımışıı. Bahsi geçen eserlerin sergide kurgulanan yollarla ve postmodern yöntemlerle daha doğrudan etkileşim halinde olduğu düşünülmüştür.

Bugünden bir göz ile değerlendirmek gerekirse, documenta 8'in teorik karmaşası, postmodern durumu anlamak açısından eğitici bir mutfak gibi gözükmektedir. Aynı zamanda sanatçıların bu teorik temelleri biçime aktarma başarısı da plastik dile yeni yaklaşımlar sunmuştur. documenta 8, amaçları konusunda başarısız bulunsa da, onun postmodernizme dair net bir tablo sunmak yerine, yeni durum ve biçimleri deneysel bir alanda sınadığı söylenebilir. Böyle bir sergiyi eğitici bir model olarak incelemek, hala güncel olan problemleri incelerken ve işlerken yeni bakış açıları kazanılmasını sağlayabilir.

Eleştiriler genelinde ortak fikir, documenta 8'in cevaplar aradığı ancak cevaplar sunamadığı yönündedir. Sergiden böyle bir sorumluluk beklemek, belki de 20. yüzyılın sanattan beklentileri ve sanatın sorumluluğu olarak görülen bakış açıları değerlendirildiğinde anlam kazanır. Ancak duruma eser ve güncel sanat tarihi açısından geniş bir perspektiften bakıldığında sanatın çözümler ve cevaplar üreten bir alan olarak görülmesi hem anlamsızlaşır hem de bunun örnekleri çok sınırlıdır. Sergi bireysel eser temelinden değerlendirildiğinde, biçimsel zenginlik ve tutumlar açısından yeni yaklaşımların geniş bir yelpazesini sunmuş, güncel bir meseleye cevap üretemeyeceği için kör kalmak yerine, elindeki malzeme ile dönemin durumu ve sanatsal birikim arasında bağlantılar keşfetmiştir. documenta 8, postmodern epistemolojinin kaçınılmaz olarak gerekli kıldığı dil yapısına biçimsel örnekler sunmuştur.

\section{KAYNAKÇA}

Bippus, E. (2005). Documenta 8 Toward Critical Discourse. M. Glasmeier, K. Stengel (Ed.), Archive in Motion. (s. 317-323). Göttingen: Steidl.

Brenson, M. (1987, 15, Haziran). Art: 'Documenta 8,' Exhibition in West 
Germany. The New York Times. https://www.nytimes.com/1987/06/15/arts/artdocumenta-8-exhibition-in-west-germany.html. Erişim Tarihi: 26 Nisan 2021.

Documenta 8. (_). Retrospective. documenta.de. https://www. documenta.de/en/retrospective/documenta_8. Erişim Tarihi: 28 Şubat 2021.

Fineberg, J. (2014). 1940'tan Günümüze Sanat: Varlık Stratejileri (Çev. S. AtayEskier ve G. E. Yılmaz). İzmir: Karakalem Kitabevi.

Rüzgar Kayıran, N. (2012). "Bir Fikrin" Başarı Öyküsü: documenta. Sanat ve Tasarım Dergisi, $1(9),---$.

Lyotard, J-F. (2019). Postmodern Durum (3. Baskı) (Çev. İ. Birkan). Ankara: Bilgesu.

O'Doherty, B. (2013). Beyaz Küpün İçinde Galeri Mekânının Ideolojisi (2. Baskı) (Çev. A. Antmen). İstanbul: Sel.

Oppermann, A. (2007). Ensembles. Generali Foundation. http://foundation. generali.at/en/info/archive/2009-2007/exhibitions/anna-oppermann-ensembles. html. Erişim Tarihi: 19 Ocak 2021.

Smith, R. (2012, 14, Haziran). Art Show as Unruly Organism. The New York Times. https://www.nytimes.com/2012/06/15/arts/design/documenta-13-in-kasselgermany.html. Erişim Tarihi: 24 Nisan 2021.

Thoreau, H.D. (1997). Devlete Karşı İtaatsizlik Görevi Üzerine (Çev. Y. Coşar). Kamu Vicdanına Çağrı Sivil itaatsizlik (s. 30-53). İstanbul: Ayrıntı. 